\title{
Sociocultural aspect of criminal law enforcement in the Russian mentality
}

\author{
Vladimir Mikhailovich Zolotukhin ${ }^{1 *}$, Rashit Saitgoraevich Bikmetov ${ }^{1}$, Vadim Viktorovich \\ Shiller ${ }^{2}$, and Anastasiya Aleksandrovna Tarasenko ${ }^{2}$ \\ ${ }^{1}$ T.F. Gorbachev Kuzbass State Technical University, Department of History, Philosophy and Social \\ Sciences, Kemerovo, Russia \\ ${ }^{2}$ Kemerovo State Medical University, Department of History and Pedagogy, Kemerovo, Russia
}

\begin{abstract}
The aim of the study is a comparative analysis of the sociocultural aspect of criminal law enforcement in the Russian mentality. The methodological basis was such scientific methods as dialectical, comparative, logical, historical, prognostic, and systems analysis. This allowed, to achieve this goal, to perform a comparative analysis of the works of Russian and foreign legal experts on the examined problem. The result of the study was the conclusion that the effectiveness of law enforcement is due not only to national mentality, but also to the sociocultural environment both on the part of the law enforcement officer and citizens as participants and/or eyewitnesses of specific legal relations. The authors also emphasize that culture, as well as socio-cultural environment forms stereotypes of legal behavior, depending on the constitutional and legislative consolidation of socio-political and socio-economic trends in the development of society. The novelty of the work lies in the formulation of the problem and its substantiation. This is due to the fact that the authors emphasize that an essential element is the degree of acceptability of value stereotypes in a particular state that allow and/or prohibit certain actions in connection with the possibility of undermining the foundations of national security and public morality.
\end{abstract}

Keywords: culture, stereotypes, socio-cultural environment, legal personality, law enforcement, mentality

\section{Introduction}

In the modern world, the process of transforming the attitude of citizens to the practice of applying the norms of criminal law and their value content is of significant importance. Law enforcement always depends on the degree of protection of the legal personality of citizens by the state, mutual observance of rights and obligations within the framework of legal culture by citizens and subjects of law enforcement. Various aspects related to the understanding of law, as well as its relationship with culture were considered in the works by Gilinskii, Zorkin, Rimskii, Volkov, Titaev, et al. The duration of criminal punishment is the basis for transforming the socio-cultural values of the prisoner, because a longer term of

* Corresponding author: zvm64@mail.ru 
imprisonment contributes to the assimilating the norms and rules of behavior that dominate in the criminal sociocultural environment. Getting into the criminal environment, a person adapts to the criminal subculture, masters its methods of communication, reproduction, identification and has an informative load both within the subculture and for the whole society. The application of "double standards" to perceiving the facts of a criminal offense leads to the fact that they are perceived as a social norm.

Any sphere of human activity, including law enforcement, is based on the value component as a way of assessing oneself from various angles. On the one hand, there are the society, its various institutions, as well as citizens who, on a daily basis, feel the possibility (positive or negative) of the action of legal norms, or are included in the process of implementing these norms within the framework of their life. On the other hand, these are subjects who, within the framework of their professional activities, assess the degree of effectiveness of the work of various institutions of law enforcement. This concerns the observance of the laws of the state and/or their reasonable violation, relying on the logic of common sense, economic expediency and stereotypes due to the national mentality.

\section{Methods}

The issues of understanding the concept of law, its relationship with culture and society were reflected in the works of Russian lawyers and sociologists Sorokin, Kovalevskii, Petrazhitskii, et al. The analysis of the relationship between the problems of law and public opinion was touched upon in the works by Gilinskii, Zorkin, Safarov, etc. Various aspects related to law enforcement were mentioned in the study of deviant behavior (Sharnegi), determination of the legal (non-legal) nature of economic self-regulation (Lapaeva), the study of the judicial system (Rimskii), as well as in the works of the Institute of Problems of Law Enforcement at the European University (Volkov, Titaev).

The methodological basis was such scientific methods as dialectical, logical, historical, prognostic, and systems analysis. This allowed, in order to achieve this goal, to analyze the works of Russian and foreign comparativists on the examined problem.

\section{Results and discussion}

The nature of law enforcement is determined by the processes of transforming social institutions and/or subcultures within the framework of interaction between the authorities and society. The formation of cultural traditions is due not only to legal normativity, but also to social factors that are significant for all subjects of law enforcement. The level of trust should correspond to the effect of the average trust of all law enforcement subjects (law enforcement agencies, the criminal world, citizens) not only to each other (playing by the rules), but also to the state power (institutions) as a guarantor of the observance of lawfulness. Turning to the statistical data, the level of trust of citizens in Russia in the judicial system is as follows: "no more than $31 \%$ of respondents trusted, that is, less than a third; did not trust - from $38 \%$ to $51 \%$. At the same time, the following reasons were indicated as the main ones for not trusting the court: citizens cannot defend their rights violated by the state in court - 33\%; judges are dependent in their decisions on the authorities and other influential groups $-31 \%$; the work of the courts is poorly organized, there is a lot of paperwork, bureaucracy $-22 \% "$ " [1].

Law enforcement, regardless of the state structure, is based on the obligation of citizens to comply with the law. Its specificity is associated with the practice of applying legal norms and sanctions due to the state-legal structure. An essential element is the attitude of citizens to the practice of applying legal norms and their actions in relation to various 
subjects of law, regardless of the social, property, etc., position in the stratification of society. An essential element is the degree of acceptability (permissibility) of value stereotypes in a particular state that allow and/or prohibit certain actions within the framework of the real and/or virtual (as fakes) existence of the possibility of undermining the foundations of national security and public morality.

This aspect can be illustrated by the example of the use of the death penalty in various states. In Russia and in European countries, the death penalty is not used. For the United States, its use is typical only in some states (in 16 states it is not used). In 12 states that have not yet abolished the death penalty, the authorities have refrained from executing it for more than ten years. In Japan and China, the death penalty is used, in particular, in the fight against corruption. In the Arab states, the death penalty follows from the understanding of Islamic law, has a variability of punishment and is based on the understanding of punishment as a certain measure (penance) within the framework of Sharia. According to Ramez, "punishment depends on the norms fixed in religious sources (Quran, Sunnah, etc.)" [2]. Moreover, in the law enforcement practice in the Arab world, "a person thinks in categories not of a civil, but mainly of a traditionally patriarchal society, is guided primarily not by individual interests, but by the attitudes and postulates of his or her clan, family, tribe, and ethnos" [3].

The implementation of law enforcement is always associated with the understanding of legal personality. While the convicts in Russia and European states are recognized as having rights, obligations and legitimate interests, as well as the importance of international standards, in US courts there are rarely references to international standards. This moment is updated if the practice of "double" standards is applied in interstate relations. For example, the situation of the US administration's restrictions in 2018 on the protection and support of people who are forced to migrate from violence and poverty from other states. As a result, as the UN Refugee Agency emphasizes, many people seek help from smugglers to cross the border in the undesignated places" [4].

According to Verkeev, "the legal system is not capable of functioning without people mobilizing its functions. The social characteristics of these people affect their behavior and the behavior of their counterparties, and all together this affects the behavior of law" [5]. The so-called "cultural status" [6] is characterized by ethno-national mentality and sociocultural identity. As Malko and Gaivoronskaya emphasize, through legislation that forms the principles and goals of legal policy, "the values are proclaimed from which power will proceed in lawmaking and law enforcement activity" [7].

The system of executing punishment in Russia and European countries, with the exception of Great Britain (MIA), is under the jurisdiction of the Ministry of Justice. It is supplemented by a probation service (suspended sentence). Probation refers to any service that executes a non-custodial sentence. There is a system of external control over the penitentiary system (the public, the prosecutor's office, the court, human rights ombudsman, etc.). The names can be different. At the same time, there is no difference in ideological approaches in law enforcement practice. At the same time, more often in Russia than in Western European countries, imprisonment is used as a punishment. According to Lapin, "about $80 \%$ of Russians share many European values. But a minority remains (15$17 \%$ of the population), with other values (self-will, including permissiveness) characteristic of archaic communities, in the Christian tradition, falling under the category of the "evil" [8].

This aspect characterizes the specifics of criminality, which depends on the sociocultural environment and mentality. At the same time, a significant role is played by the practice of law enforcement itself [9], including criminal law [10]. It concerns the terms of imprisonment - in the West, on average, it is 5 months, in Russia - 5 years. The latter is the basis for transforming the prisoner's socio-cultural values and is the basis for transforming 
and reproducing crime as a subculture, with its inherent customs, traditions, language, symbols, etc.

For example, Razumova notes that during their stay in correctional labor institutions, criminals serving sentences for criminal acts with a total term of imprisonment of more than 5 years undergo changes in the structure of the psychological properties of the personality, leading to committing repeated offenses [11]. Moreover, Knorre and Titaev note that: "the most important observation is that more than $30 \%$ of the criminals who committed looting and/or robbery, fraud, and threat, were previously familiar with the victim. For attacks, this share reaches even $40 \%$. This once again confirms the thesis that in Russia crimes are committed within the same social environment, and are not aggression by the criminal subculture against other citizens" [12, p. 21].

Being more fatalistic and melancholic people, unlike law-abiding citizens, criminals have an underestimated need for socially acceptable self-regulation. It concerns a combination of personal properties (a kind of "symptom complex"), which characterizes a delinquent personality as a person with a special "life philosophy" and behavioral stereotypes [13]. Being in an antagonistic relationship to the official culture, the criminal subculture parasitizes on universal human norms, and such values as a sense of civic duty are replaced by the concept of a thief's duty, friendship - by loyalty to a leader or a criminal group ("thief's family"), etc.

The political interpretation of human rights and freedoms, moreover, the application of "double standards" to perceiving facts of a criminal offense (corruption, murder, terrorism, etc.) leads to the fact that they are perceived as a social norm. At the same time, the daily formation of value stereotypes on the part of various mass media, social networks and messenger channels is of decisive importance, where criminal offenses are encouraged, and "often "unmotivated" [14]. From the point of view of cultural studies, according to Kemerov, a person is viewed in all his or her uniqueness and originality. Proceeding from this, "cultural value is, in principle, the opposite of abstract dimensions and reductions" [15]. It should also be taken into account "that long-term isolation of a person from a rapidly changing society significantly reduces the possibility of his or her full return to normal life" [16]. It manifests itself through the concrete interaction of various subjects with each other [17], as well as in the field of law enforcement, both from the point of view of its subjects [18], and the implementation of the legal policy by the state.

\section{Conclusion}

The value aspect of criminal law enforcement influences such elements as: the everyday attitude of various subjects to law and legal norms, the degree of demand for value stereotypes among various social groups of legal regulation, state policy in the field of lawmaking and various degrees of citizen protection (selectivity) in the law enforcement process. The effectiveness of law enforcement is due not only to the national mentality, in a particular Russian one, but also to the socio-cultural environment both on the part of the law enforcement officer and citizens as participants and/or eyewitnesses of specific legal relations that affect the citizen's awareness of the degree of positivity and/or negativity of state coercion.

\section{References}

1. Yu.A. Nisnevich, Sociol. Research 8, 84-95 (2019). https://doi.org/10.31857/S013216250006165-4 
2. A.E. Ramez, Nakazanie po ugolovnomu pravu arabskikh stran [Punishment in the criminal law of Arab countries], $\mathrm{PhD}$ thesis in Legal Science (Moscow, 2002)

3. Kulturnye aspekty i pravoprimenitelnaya praktika $\mathrm{v}$ oblasti prav cheloveka $\mathrm{v}$ arabskom mire [Cultural aspects and human rights law enforcement in the Arab world] (Publishing House of the Higher School of Economics, Moscow, 2011)

4. V UVKB prokommentirovali novye pravila predostavleniya politicheskogo ubezhishcha $\mathrm{v}$ SShA [The UNHCR commented on the new rules for granting political asylum in the United States]. Accessed on: June 25, 2021. [Online]. Available: https://news.un.org/ru/story/2018/11/1342481

5. A.M. Verkeev, Monitor. Pub. Opin.: Econ. and Soc. Changes 3, 91-109 (2018)

6. D. Black, Povedenie zakona. Glava 1. Vvedenie, Glava 2. Stratifikatsiya, Chast 1 [Behavior of the law. Chapter 1. Introduction, Chapter 2. Stratification, Part 1], in E.L. Paneyakh (ed.), Pravo i pravoprimenenie v zerkale sotsialnykh nauk: khrestomatiya sovremennykh tekstov [Law and enforcement in the mirror of social sciences: a chrestomathy of modern texts] (Statut, Moscow, 2014)

7. A.V. Malko, Ya.V. Gaivoronskaya, Law. J. Higher Sch. Econ. 1, 4-25 (2018). https://doi.org/10.17323/2072-8166.2018.1.4.25

8. N.I. Lapin, Sociol. Research 3, 4-14 (2018). https://doi.org/10.7868/S0132162518030017

9. V.M. Zolotukhin, A.A. Tarasenko, Bul. Kemerovo State Univ. Human. and Soc. Sci. Ser. 3, 55-60 (2017)

10. A.A. Tarasenko, Bul. Kemerovo State Univ. Cult. and Arts 44, 55-61 (2018)

11. E.M. Razumova, Psikhologicheskie osobennosti lichnosti prestupnikov retsidivistov [Psychological characteristics of the personality of repeat offenders], PhD thesis (Saint Petersburg, 2007)

12. A. Knorre, K. Titaev, Prestupnost i viktimizatsiya v Rossii. Rezultaty vserossiiskogo viktimizatsionnogo oprosa. (Analiticheskii obzor) [Crime and victimization in Russia. Results of the All-Russian Victimization Survey. (Analytical review)] (Institute of Problems of Law Enforcement at the European University Saint Petersburg, Saint Petersburg, 2018)

13. A.R. Ratinov, N.Ya. Konstantinova, E.M. Sobchik, Samootsenka prestupnikov [Selfesteem of criminals], in Lichnost prestupnika kak obekt psikhologicheskogo issledovaniya [Personality of a criminal as an object of psychological research]: Collection of scientific papers (Moscow, 1979)

14. V.E. Krukovskii, I.N. Mosechkin, Law. J. Higher Sch. Econ. 4, 196-215 (2018)

15. V.E. Kemerov, Quest. Philos. 6, 89-98 (2018)

16. O. Shepeleva, Prestuplenie i nakazanie: chto delat s rossiiskimi tyurmami [Crime and punishment: what to do with Russian prisons], in All-Russian Civil Forum, 55 (Moscow, 2019)

17. T.I. Gritskevich., E.F. Kazakov, A.V. Konovalov, Value of reforming social and economic models of interaction in society development, in The European Proceedings of Social \& Behavioral Sciences, 420-428 (2017). https://doi.org/10.15405/epsbs.2018.02.49

18. V. Zolotukhin, A, Belkov, E. Stepantsova, M. Kozyreva, A. Tarasenko, Demographic and migration policy in the mining region and its impact on the ecological consciousness of the population, in E3S Web Conf. The 1st Scientific Practical 
Conference "International Innovative Mining Symposium (in memory of Prof. Vladimir Pronoza)", 15, 04015 (2017). https://doi.org/10.1051/e3sconf/20171504015 